Koch, Andrew M. (1993) "Poststructuralism and Epistemological Basis of Anarchism" The Philosophy of the Social Sciences, 23: 3 [September 1993] pp. 327-351. Published by SAGE. DOI: 10.1177/004839319302300304 (ISSN: 0048-3931)

\title{
Poststructuralism and the Epistemological Basis of Anarchism
}

\section{Andrew M. Koch}

\begin{abstract}
This essay identifies two different methodological strategies used by the proponents of anarchism. In what is termed the "ontological" approach, the rationale for anarchism depends on a particular representation of human nature. That characterization of "being" determines the relation between the individual and the structures of social life. In the alternative approach, the epistemological status of "representation" is challenged, leaving human subjects without stable identities. Without the possibility of stable human representations, the foundations underlying the exercise of institutional power can be challenged. This epistemological discussion is traced from Max Stirner to the twentieth-century movement known as poststructuralism.
\end{abstract}

\section{Introduction}

The problem of defining the "proper" relationship between the individual and the larger community is as old as civilization. Classical and Modern political theory have traditionally addressed this problem by grounding descriptive and prescriptive political formulations in conceptions of human nature, or human essence. Questions regarding the aggressiveness, avarice, and rationality of the individual have provided the underlying dynamic for the debate regarding the necessity and form of external institutions. 
In the classical and modern periods the conflict over how to "represent" the character of the individual culminated in a variety of competing political formulations. If human beings are self-serving and aggressive the strong coercive state becomes necessary. If the individual is shaped by the social body, then community practice becomes the essence and the teleology of human endeavors. If human beings are rational, to the extent that they can formulate a structure for controlling their aggressiveness, then conflicts can be mediated. "Authority" becomes a substitute for force, and participation and consent provide the legitimacy for collective decisions.

Within this general framework the writings of classical anarchism can also be examined. The Eighteenth and Nineteenth Century anarchists' attacks on the state were based on a "rational" representation of human nature. Reason, compassion, and gregariousness are essential to this view of anarchism. Not only is the state, as a coercive institution, fundamentally in conflict with this view of human nature, but the rigid monolithic character of its structure inhibits both the spontaneous character of association and the expression of genuine human kindness. And, although the foci of the classical anarchists differ, and their prescriptions vary, the general ontological character of their argument is similar.

This paper will explore the origins and evolution of another perspective within the archeology of ideas. As an epistemological problem, the relationship between the individual and the collective takes on a fundamentally different character. The major question is no longer one of "representation" but of "validity." By what measure can any ontological characterization of "essence" or "nature" be justified? Is there any validity to the representation of human nature that underlies state practices?

The paper will attempt to demonstrate how the general critique of Enlightenment epistemology, beginning in the Nineteenth Century and continuing today in the work of the poststructuralists, may be recast to assist in the construction of an epistemologically grounded defense of anarchism. After briefly outlining the ontological justification for anarchism found in the works of Godwin, Kropotkin, and Proudhon, the focus of the paper will shift to epistemological issues. First, the general questions raised by Max Stirner's defense of anarchism 
in The Ego and His Own will be examined. Then, Nietzsche's critique of Enlightenment epistemology will be surveyed for the questions it raises about truth, knowledge, and method. Finally, the epistemological questions raised by the Twentieth Century movement known as poststructuralism will be explored for their relevance in reformulating the support for the objectives of anarchism.

The paper will conclude by challenging the claim that poststructualism cannot create a rationale for resistance to the state. Poststructuralism confronts the state by undercutting the foundational premises that support the state rather than offering a competing ontology of the subject. Rejecting the modernist epistemology and universalist ontology the poststructualist's argument asserts a plurality of contexts for the generation of discourse. The recognition of plurality becomes the basis for resistance to that which would impose universals. In political terms, that resistance is directed against the state.

\section{Ontological Justifications for Anarchism}

The central feature of the ontological defense of anarchism is a representation of "human nature." One of the most clearly elaborated ontological defenses of anarchism can be found in William Godwin's Enquiry Concerning Political Justice. The essence of Godwin's argument is found in his characterization of the perfectibility of human nature. Human beings are perfectible, not because each is able to reach a final condition, but because each is capable of continually improving. (Godwin 1976, p. 144) The perfectibility of human nature is associated with the quest for truth and justice which is, in turn, generated by the power of reason.

Godwin asserts a set of propositions regarding the character of human nature and then draws logical inferences from those assertions. Godwin believed that all human beings are equal in that they have an innate ability to reason. (Godwin 1976, p. 231) The problem in society, then, is not to find the perfect person to rule but to cultivate sufficiently the reasoning capacities of all individuals. Once we have sufficient confidence in our own reasoning abilities, our acceptance 
of rule by others will be shaken. Confidence in others is the offspring of our own ignorance. (Godwin 1976, p. 247)

At this juncture the characterization of human nature, government, and power are linked to a transcendental notion of truth. "Truth" and "justice" have an abstract condition of existence in which the world has only imperfect manifestations. "...[T]ruth is omnipotent." (Godwin 1976, p. 143) Vices and moral weakness are founded on ignorance. (Godwin 1976, p. 143) Truth will be victorious not only over "ignorance" but also over sophistry. (Godwin 1976, p. 140) In order for this victory to occur, however, the truth must be communicated. (Godwin 1976, p. 140) Man's perfectibility takes place as he uncovers the truths of his existence and communicates them to others. Governments, which have become the foundations of inequality, exist because of ignorance. As ignorance declines, so will the basis of government. (Godwin 1976, p. 248) The same strategy for the justification of anarchism is found in the work of Peter Kropotkin. Kropotkin bases his analysis of mankind on a conception of universal animal nature. In contrast to Darwin, Kropotkin asserted that human survival has been enhanced by cooperation, not competition. Most animal species that have survived use "mutual aid" as a tool for survival. From this naturalistic observation, Kropotkin suggested that the history of the human species also shows the tendency toward cooperation. However, this natural condition has been mitigated by social conditions in the modern age. Since the Sixteenth Century, with the emergence of the centralized nation state and the economic logic of capitalism, the institutions that supported "mutual aid" among the human species have been in retreat. (Kropotkin 1987, p. 203, 208)

To Kropotkin, "progress" is measured according to those institutions that extend the natural condition of mutual aid. (Kropotkin 1987, p. 180) Modern institutions, however, corrupt the individual. The undesirable traits in human beings will be eliminated by disposing of the institutions that promote such characteristics. (Kropotkin 1988, p. 83) Kropotkin acknowledged that this will not be easy to achieve because the law serves the ruling class. (Kropotkin in Gould and Truitt, p. 450-451) 
Pierre Joseph Proudhon presented a similar ontological justification for anarchism. In the volume What is Property? Proudhon argued that the idea of property was not natural to the human condition. (Proudhon 1966, p. 251) The system of property leads to inequality that can only be maintained by force. Proudhon was, however, equally critical of state communism. Communism oppresses the various faculties of individuals. (Proudhon 1966, p. 261)

In place of either of these systems Proudhon proposed a form of social organization he called "liberty." For Proudhon, liberty is the condition in which mankind is capable of exercising rationality in the organization of society. (Proudhon 1966, p. 283) Liberty brings the body of scientific knowledge to political questions. Political truths exist and can be understood by rational scientific inquiry. (Proudhon 1966, p. 276) To the extent that a society is enlightened, the need for oppressive state authority diminishes. Ultimately, the human potential for reason will replace the oppressive state.

This sample of writers clearly does not exhaust the list of anarchists in the Nineteenth Century. It is, however, a representative sample of a particular approach to anarchism in which several recurring themes emerge. While the characterization of the human being differs slightly among the authors, they share a common concern for the delineation of the human character in order to proceed in their critique of the contemporary order. While the representational character of this methodology is my primary interest, it should also be noted that the content of that representation is similar in the authors mentioned. The human being is seen as a rational, cognitive, and compassionate creature. Corruption takes place within social institutions and is not an essential part of human nature. As reason takes mankind toward the "truth," rational individuals lose their need for the state.

\section{Origins of an Epistemological Defense of Anarchism}

In contrast to an ontological defense of anarchism, an epistemologically based theory of anarchism questions the processes out of which a "characterization" of the individual occurs. If the validity of any representation can be questioned, then the political structures that rest on that 
representational foundation must also be suspect. If the conditions for the existence of the truth claims embraced by the political order are demonstrated to be suspect and if the representations by which the character of the state is propagated and legitimated are open to interpretation, doubt, or are shown to be grounded in "fiction," then the authority of the state may be legitimately questioned.

The elements for an epistemologically based critique of the state can be traced back to the Nineteenth Century in the writings of Max Stirner and Friedrich Nietzsche. In the contemporary world the same challenges to the Enlightenment view of knowledge, and ultimately the state, can be found in the writings of the poststructuralists.

\section{A. The Nineteenth Century Attack on Representation}

\section{Max Stirner}

Max Stirner's 1845 The Ego and His Own is a subjectivist's defense against the power of the state. What is unique about the work, especially in relation to other Nineteenth Century anarchist thought, is the method Stirner employed for his defense of egoism. Stirner's main task is not to construct an alternative view of human nature, but to suggest that the systems of thought which have been employed in the Western philosophic and political tradition are based on an error. The error is that they construct a "fixed" idea of the human being and then seek to construct man in the image of the idea. Thoughts and conceptions, themselves, become the chains that seek to enslave us. We are prisoners of our conceptions. (Stirner 1973, p. 63)

Stirner traces the emergence of the "idea" in the history of Western thought. Ancient man was concerned with the world, and the world was its own truth. The mind was to be used as a weapon, a means against nature. (Stirner 1973, p. 17) But the world is finite and the world is in a constant state of change. Therefore, truth is a fleeting moment. This was an unsettling position for modern man.

Stirner identified the transformation to the modern age with the emergence of spiritualism and the creation of static concepts. Specifically, he argued the modern age emerged with the 
decline of ancient civilization and the rise of Christianity. Asserting that the modern age is characterized by the notion of the "idea" or "concept," Stirner suggested a natural affinity between the spiritualism of modern philosophy and the spiritualism of Christian thought. Whether in spiritual or secular matters, both convey the same "foolishness" of the fixed idea. (Stirner 1973, p. 44)

Stirner claimed the individual loses uniqueness in the face of the generalized and fixed concept "Man." This is especially relevant in the area of politics. Stirner surveyed what he considered three types of "liberal" thought: political, social, and humane. Each ultimately rests on the creation of an image to which humans must conform. Political liberalism is only possible through the creation of the idea of citizenship. It transforms the individual into citizen, in the image of the state. (Stirner 1973, p. 107) Social liberalism robs people of their property in the name of "community." (Stirner 1973, p. 117-118) However, it is humane liberalism which, because of its subtlety, may be the most insidious. Humane liberalism removes uniqueness of human beings, and turns the real living ego, "man," into the generalized concept "Man." (Stirner 1973, p. 128) The individual is lost to the concept. Servitude continues in the name of humanity, rather than to God, King, or country. Stirner rejected all three of these "liberal" formulations and sought to find a place for "man" that has been lost in the modern age.

Stirner opposed the attempt to formulate a notion of human "essence," (Stirner 1973, p. 81) yet his alternative is clearly not wholly successful. He is aware of the problem but lacks the linguistic tools for a reformulation. He, therefore, lapses into his own characterization of the human subject at various points throughout the work. This leaves the work as a whole unable to remove the notion of the historical subject, even within a general attack on its characterization.

The significance of the work is clearly in its reformulation of the methodological problem; Stirner's position is an early formulation of the attack on "representation." This is reflected in his condemnation of "concepts," "principles," and "standpoints" that are used as weapons against individuals. (Stirner 1973, p. 63) More generally, Stirner's attack has the character of a universal condemnation of "ontological culture." The culture of "being" and the 
representations of that "being" are characterized as suspect, at best, and dangerous, at worst. Rather than focus on a competing model of human nature Stirner was concerned with showing the linkage between ideas and the context in which they are generated. This method is similar to that which will be labeled "genealogy" by Nietzsche and the poststructuralists.

\section{Nietzsche, Genealogy, and the Problem of Language}

In the latter half of the Nineteenth Century Friedrich Nietzsche created a language with which to analyze the presuppositions that underlie the Enlightenment view of knowledge. Nietzsche denied the validity of Kant's assertion that there is a transcendental reality of which our knowledge is limited. In denying the existence of a transcendental realm of "things-inthemselves," Nietzsche is raising doubts about the foundation upon which the entire Enlightenment enterprise has been built. The magnitude of this assertion cannot be overemphasized.

Whether one subscribes to the Platonic notion of the "forms," adheres to the Kantian notion of a "thing in itself," or defends the Hegelian totalizing teleology of world history, to Nietzsche these are nothing more than "fictions." Each of these systems of thought suggests that there is a sub-stratum to reality in which the "true" causal dynamic of world events resides. Thus, what has passed in history as epistemology has been little more than metaphysics. (Nietzsche 1957) Science also rests on presuppositions, the truth of which cannot be proven. (Nietzsche, "The Gay Science" in Nietzsche 1968, p. 449-450) For Nietzsche, the world is neither true nor real, but living. (Deleuze 1983, p. 184)

Nietzsche will not deny these fictions have served a utility function in human history. At the beginning of The Use and Abuse of History Nietzsche suggests that the drawing of a line to establish a specific horizon, distinguishing the knowable and unknowable, the visible and invisible, allows for the generation and reproduction of "knowledge" and "culture." (Nietzsche 1957, p. 7) Within the metaphysics of culture, falsity and narrowness appear as a virtue when compared to the intellectual paralysis generated by ever shifting horizons. (Nietzsche 1957, p. 8) 
At this point an epistemological paradox around the idea of "exclusion" appears. To generate knowledge, particularly of history and culture, one must continually limit the universe of one's objects, closing the system. One must draw a boundary around that which is relevant. But to do so takes the phenomenon outside the context of its occurrence. This process negates the possibility of truth. Therefore, history never contains truth; it is the past transformed to resemble the present. (Nietzsche 1957, p. 15)

Cultural and historical analysis create fiction. This is logically true, regardless of the utility contained within the proposition. Because the past is continually reconfigured to resemble the present, any notion of an ahistorical universal is absurd. The historical character of truth is also reinforced in a second way. Because truth does not and cannot exist apart from those who possess it, and since those beings are historical entities, truth is an historical phenomenon. (Strong 1988, p. 44)

If universal truth is denied, then the domain of intellectual inquiry is transformed. The quest for knowledge is not satisfied by representations. There is no longer the possibility of stating "truth" about human beings or nature. Representations of "being," "truth," and the "real" are only fictions. (Nietzsche 1967, p. 266)

If this is accepted, then there remains a two-fold intellectual task. The first is to unmask the existing structure of culture in order to reveal its metaphysical illusions. This is done through what Nietzsche calls "genealogy." The second task is to return to the individual a conception of life stripped of its illusion. This is represented by the "will to power."

These ideas are clearly related. If the will to power is in part the will to truth, which Nietzsche suggest it is, and if the ideal of truth does not reside in "true reality" it must be contained in the medium of "truth," language. Language contains the concepts which characterize the world. The genealogical method explores the process by which "facts" acquire their status from the utility function they serve in the language of history.

Nietzsche's genealogical exploration is concerned with the way in which the "facts" of the contemporary world have been created. Of particular interest is the creation of morality. To this 
point in history, claimed Nietzsche, the intrinsic worth of values had been taken for granted, and they must be called into question. (Nietzsche 1956, p. 155) "[W]e need to know the conditions from which those values have sprung and how they have developed and changed: morality as a consequence, symptom, mask..." (Nietzsche 1956, p. 155)

Questioning the origin and status of values suggests the link between language, knowledge, and power which will be an essential component of the poststructuralist claims. Language expresses a set of conceptualizations about the world. And, because the person who makes a statement using the concepts contained in language is not making an objectively "true" statement, the world of appearance is a creation of those who speak and give the world its image. (Nietzsche "The Gay Science," 58, II)

Thus, Nietzsche asks "who speaks?" when moral positions are asserted. In exploring the genealogy of the concept "good" Nietzsche claimed that its genesis was in the utility it served for the nobles. (Nietzsche 1956, p. 160.) As the concept of "good," originally associated with the actions of the nobility, is adopted by the lower strata the concept loses its necessary connection to the existence of an aristocracy. Yet the association of "good" with "noble" remains ingrained in the language.

The problem created by this representation of moral virtue is that it generates a "fixed" characterization of human nature. This is true whether the characterization of human nature is "good" or "bad." In fact, Nietzsche claims the characterizations of "good" and "bad" are dependent on each other, suggesting no knowledge at all is conveyed by their usage. However, the result of this characterization is a fixed, ahistorical notion of morality that can be applied to individuals. Society becomes immersed in the process of sorting the "good" from the "bad" and assigning responsibility based on that characterization.

By denying the possibility of a moral representation of human nature, Nietzsche brings into question the process which has dominated the political experience of the Western world. If morality has its basis in interest rather than truth, the foundations which underlie political assertions of "right" and "justice" are also obliterated. Claims of the state have their genesis in 
the interests of those who created the language of "justice." In the same way, the interests of the commercial classes and the royal dynasties created the concept of nationalism. (Nietzsche in Kaufmann 1968, p. 61.)

If politics cannot be organized around "truth" because it lacks transcendental grounding, and politics cannot be organized around "justice" because its representation reflects the interest of the one who defines it, then politics is reduced to the expression of power. The state is organized immorality. (Nietzsche 1967, p. 382) It represents the "idolatry of the superfluous." (Nietzsche in Kaufmann 1968, p. 162) The morality of the state is the instinct of the "herd" with the force of numbers providing legitimation for its actions.

Yet it is still difficult to argue that Nietzsche was an anarchist. His political doctrine may, in the final analysis, be closer to the Aristotelian notion of a "natural aristocracy" than to anarchism. Nevertheless, Nietzsche's contribution to an epistemological justification of anarchism is monumental.

By replacing the creation of "facts" with the genealogical enterprise, Nietzsche suggested a method for the critique of all existing knowledge. Nietzsche's main focus, however, was on the genesis of Western values. Nietzsche's question in the Genealogy of Morals is," Under what conditions did man construct the value judgements 'good' and 'evil'?" (Nietzsche 1956, p. 151) In the Twentieth Century the poststructuralists extend Nietzsche's question to a more comprehensive critique of knowledge. Under what conditions does contingent knowledge become "fact?"

\section{Poststructuralism and the Critique of Enlightenment Epistemology}

Inspired by Nietzsche and Linguistic Philosophy the movement of poststructuralism in the late Twentieth Century continues to challenge the Enlightenment epistemology. The works of Jacques Derrida, Michel Foucault, and Jean-Francois Lyotard, as three of the most notable members of the poststructuralist movement, all signify a break with what they perceive to be an epistemology based on the "fixed idea." These authors, and other poststructuralists, reflect a shift 
away from the ontological character of the human discourse that dominated the Eighteenth and Nineteenth Centuries.

In analyzing the problems with Enlightenment epistemology the common features of the poststructural position emerge. Reacting specifically to the structuralism of Saussure and LeviStrauss, the poststructural criticism is a comprehensive critique of the idea of "representation." Linked to the questioning of "representation's" status and the rejection of a fixed conception of human nature is the denial of the "grand narratives" that underlie mass politics.

With the attack on representation there is an implicit negation of any fixed content for "subjectivity" in social and historical discourse. The poststructuralists reject what they consider the ontological character of modern individualism, which has provided the foundation for Nineteenth and Twentieth Century liberal ideology. They also reject the teleological character of Twentieth Century Marxism.

The poststructuralists challenge the idea that truth and knowledge are simply the result of a linear accumulation of "facts" about objects in the world. Science, economics, culture, and politics change as the language, concepts, ideas regarding what is acceptable as "truth" change. Thus, the linear view of knowledge is replaced with a conceptualization of knowledge that is contingent on a plurality of internally consistent "episteme." It is this idea that raises questions about the foundational basis of the modern state.

\section{$\underline{\text { A. Representation, Language, and Truth }}$}

Of central concern to the poststructuralists is the contrast between the modern and postmodern understanding of knowledge. At the center of this debate is the status of "representation." "Representation" signifies a process by which experience is turned into the signs of experience, which can then be ordered for recovery and use. Whether ordered from appearance (Classical Episteme) or according to function (Modern Epistme) the epistemological

problem remains. The epistemology of representation requires a closed system. This is the only way that the identities of the "signified" can remain stable. (Laclau in Ross 1988, p. 73.) 
The attack on representation is an attack on the idea of a closed system. (Arac xxii) The argument centers on the claim that a closed system always omits an element that is contained in the object that it seeks to describe. In addition, the idea of representation fixes the meaning of the "sign" outside of its context, making the communication through the use of signs almost meaningless. (Derrida, 1982 pp. 299-301.) The poststructuralist critique of representation links the process of concept formation to the production and reproduction of language. (Benhabib 1987, pp. 106-109.) The attack on representation results in the conclusion that the communication of intended meaning is always inhibited because the meaning of the sign can never be clearly communicated.

In place of the idea of representation, poststructuralism uses the model of grammar as the framework for statements. (Foucault 1973, p. 237.) The paradigm of language replaces the paradigm of consciousness. (Benhabib 1987, p. 110.) The shift to the model of grammar for the context of knowledge formation has several important features. First, grammar contains its own internal laws governing discourse, regardless of the content of the message. The rules governing the truth claims of the message are then internal to the system of language itself, and do not require the construction of an external system of verification. Second, since the verification of signs and symbols occurs internally, there is no possibility of a meta-language which links the various languages. (This is the focus of Lyotard's argument in The Postmodern Condition.) Third, because each language has different symbolic referents, statements must be context specific. This makes the communication across different systems of language difficult, if not impossible. Finally, with the plurality of possible grammatical systems, and the context specific nature of their claims, irreconcilable tension must exist among heteromorphous language systems.

This assertion clearly distinguishes the position of the poststructuralists from the critical theory of Jürgen Habermas. Habermas argues it is possible to transcend the "subject-centered" reason in the formulation of rules governing discourse. (Habermas 1990, p. 341.) It is possible, therefore, to deduce an "ideal speech" situation in which discourse occurs that is free from the 
influence of institutionalized power. But if the poststructuralists are correct, what would such a speech situation produce? Despite his denial, Habermas must assume a form of Kantian universalism if the outcome of ideal speech is to be meaningful. This denies the heteromorphous nature of systems of grammar and the context specific use of the sign. To the poststructuralists the ideal speech situation will produce skewed languages speaking at one another, neither "truth" nor consensus.

In linking the production of truth to the production of heteromorphous languages the poststructuralist renew the Nietzschean idea of genealogy as the method of inquiry for social practice. The Nietzschean question of "who speaks" in the realm of discourse suggests that the conditions which gave rise to an assertion of truth are the proper focus of investigation. The concentration provides the basis for an analysis that is not dependent on the idea of a transcendent subject. (Foucault 1980 "Truth and Power") The real question is not what something "is" in itself. There is no such meta-language that can support the idea of "essence." Genealogical analysis focuses on the context that makes a statement of "this is" possible. In describing the application of this method to the study of the prison, Foucault states he studies the practice of imprisonment to understand the "moral technology" in which the practice of imprisonment becomes accepted as natural. (Foucault 1981, p. 4-5.) Thus there is a direct connection between the accepted practice and the production of "truth" which supports that practice.

The important questions for the poststructuralists pertain to the assumptions and complex social relations in which language is produced, reproduced, and validated. The task of poststructural analysis is not to replace one set of axiomatic structures with another, but to provide a "reading" of scientific, cultural, and social texts such that the contradictions, assumptions and aprioris are made explicit. (Aronowitz in Ross 1988, p. 55.) Only in this way can the connections among language, the production of truth, and the institutions of power be made apparent. 


\section{B. Epistemological Relativism and the Critique of Power}

The poststructuralist are concerned with the epistemological status of discourse, but as they clearly indicate, their position has political implications. The political side of their epistemological critique links the context in which political statements are formulated to the institutions which generate the rules and procedures for institutional discourse. As Foucault asserted, all institutions of power have a mechanism for generating and controlling discourse. (Foucault 1980, p. 93) This discourse not only generates a legitimating discourse for that institution, but also controls the right to speak within the institutional framework. (Foucault 1977, p. 214.) The political-epistemological link, therefore, connects the production of knowledge with the production of power. By examining the process in which what is called "knowledge" comes to be labeled as such, and by claiming that the label of "knowledge" is tied to a specific historical context for the production of knowledge, the poststructuralists seek to undermine the foundations from which the dominant political ideologies of the Twentieth Century have drawn their legitimacy. If the concepts under which action is coordinated are fictions, then the legitimacy of those actions is open to question.

Poststructural analysis of the political environment substitutes a focus on epistemology for the modernist focus on ontology. The concern changes from "what is human nature," to "how have we come to this belief about human nature." This epistemological focus decenters the understanding of politics because it suggests heteromorphous arenas for the production of "truth." Languages emerge in a plurality of episteme. A plurality of languages requires the decentering of politics.

If poststructuralism counters the universal claims of the modernist epistemology and replaces them with a notion of plurality and contingency, then poststructuralism can challenge the content of the dominant ideology without the substitution of one "popular truth" for another. (Ross 1988, p. ix.) Where no apriori exists regarding the subject, there can be no universal regarding politics. The poststructuralists argue the human discourses need to give up universals. (Mouff in Ross p. 34.) 
If truth is relative to the construction of a language in which taxonomies, concepts, and "facts" are used to judge and regulate activity, then "truth" is not something to be discovered, but something that is produced. The poststructuralists claim that the creation of knowledge needs to be understood as a process in which contingent value is replicated within a closed epistemological system. For this reason there is a link between the social, economic, scientific, and political discourses within any society. "In any given culture and at any given moment, there is always only one episteme that defines the conditions of possibility of all knowledge, whether expressed in a theory or silently invested in a practice." (Foucault 1973, p. 168.) Each episteme supports a different form of domination. In any given period, then, the system in which knowledge is produced and reinforced maintains the political order.

The poststructuralists oppose the tyranny of globalizing discourse on any level. (Foucault 1980, p. 80, p. 83.) The methodologies suggested by Derrida, Foucault, and Lyotard, (deconstruction, genealogy, and paralogy) are all designed to decenter the production of language and "truth" to more accurately reflect the contingent and relative character of knowledge. Society contains a plurality of heteromorphous languages. Genealogical analysis reveals that history has been a struggle among these languages. (Foucault 1980, p. 83.)

At this point the attack of the poststructuralists appears entirely negative in character. There is no possibility of truth, there are only contingent "truths." There are no legitimating foundations for politics. There are only power struggles in which the power is masked, effectively or ineffectively, in the production of legitimating discourse through self-replicating institutions of power. The existing political order is generated from a language of representation that is context specific and insupportable in its universalism.

\section{Poststructuralism, the State, and Anarchist Theory}

While it cannot be asserted that the poststructuralists "are" anarchists, several aspects of the poststructuralists position have particular importance for an epistemological formulation of anarchism. The attempt to fix human nature, or to create any idea of human essence is clearly 
rejected. The idea that legitimacy can be grounded in "process" is also suspect. (e.g. see Derrida 1982, p. 304) The poststructuralist position also eliminates any idea of historical inevitability or teleology. History is the discourse of the present projected onto the past.

In general, poststructuralism provides the tools for a systematic deconstruction of the claims to legitimacy for any institutional authority. If truth determines how we live, and the production of truth is relative to a particular episteme and the corresponding constellation of power, then how we live is ultimately determined by power, not truth in either the Platonic or the Kantian sense. Dismantling the myths on which politics is based, demonstrates the prejudices of existing practice. Removing the possibility that the state can be based on truth, reveals the existing structures of power in social relations.

However, despite this stance regarding the institutions of power, Jürgen Habermas (Habermas in Foster 1983), Stephen White (White 1988, p. 190.), Stanley Aronowitz (Aronowitz in Ross 1988, p. 48.), and others, argue that in denying the possibility of authoritative values, the poststructuralist's position lacks the ability to provide a normative defense of the individual. They argue that while the poststructuralist's focus on the historical and epistemological contingencies in which power arose may provide descriptive statements, this position is not sufficient to make a choice regarding the existing relations of power. For this reason Jürgen Habermas identifies poststructuralism as a neoconservative attack on foundations of modernism. The poststructuralists, claims Habermas, are not able to make any determinations of what is "just" and "unjust."

But to Foucault and the other poststructuralists the claims of critics like Habermas, White, and Aronowitz are based on an ontology and universalism that are characteristic of modernism. The modernist critics of poststructualism support their critique of power with an ontology of the subject that is then contrasted with what they consider the prevailing ideology. The content of concepts such as "just" and "unjust" are tied to the ontological strategy that underlies modernist politics. While it is accurate to say that Foucault suggested the study of social interaction should reveal the structures of power that lead to representations of "just" and 
"unjust," it is equally true that Foucault concluded his analysis by saying the real target is power and the legitimating mechanism that serves power. (Foucault 1977, p. 211.)

The political question that emerges from the poststructuralist's strategy concerns what remains after the epistemological critique of power. Is there any type of politics that can be defended? It is into this space that the epistemological foundation of anarchism emerges.

\section{The Epistemological Basis of Anarchism}

The central problem for anarchist theory, in the light of the poststructuralist critique of power and knowledge, is to build a non-representational basis of anarchism. A new theory of anarchism cannot be based on the ontological assumptions contained within the classical anarchist literature. The characterization of human beings as "benevolent" or "rational" cannot be sustained with any more certainty than the claims that human beings are "selfish" and "irrational." Anarchism must find its grounding outside any fixed structure.

There are three paths that can be taken in reconstructing a justification for anarchism in the aftermath of poststructural theory. The first focuses on the contingent nature of knowledge. Anarchy is the "real," empirical character of society without its facade. The second argument suggests that anarchism is the only possible normative position toward the state given the plurality of validating episteme. If there is no condition under which a particular normative condition can be validated, then the plurality represented by the anarchist position is unassailable. The third possibility suggests moving the political context away from the notion of "representation" toward a non-ontological conception of individuality. The first two suggestions are essentially negative in character. The third offers the possibility for a positive political critique from within the general framework of the poststructuralist epistemology.

\section{A. The Empirical Assertion of "Anarchy"}

The assertion that there is no foundation for truth means that a claim "to know" is contingent upon its respective episteme. All statements must reflect the context in which 
discourse is generated. Discourse is a mediated process of conceptualization relative to the constrictions of language.

Experience cannot be "recaptured" by language. The closed grammatical and semantic system used for discourse must, by its nature, omit elements of experience. Any attempt to categorize or reformulate experience creates fiction. A reconstituted experience takes the forms, categories, and concepts, created in an historical and collectively grounded context. "Reflection" upon experience is, therefore, historical context reflecting back upon itself.

If discourse is relative to the governing episteme, and if all claims to truth are subject to those same constraints, then the ability to formulate a universally valid, rational or normative discourse would be impossible. If that is the case, the discourse that has come to rationalize the existence and functioning of the state within the modernist episteme is valid only within the closed and constrained sets of assumptions and concepts that constitute its context. Given that meaning in discourse is generated by metaphorical reference to individuated experience, and that those individuated metaphorical references are plural, the communication of intended meaning is impossible. Within this epistemological framework, the idea that consensus can be achieve in political discourse through the imposition of a structural context, whether democratic or otherwise, is reduced to nonsense. Taken together, the relativity of both ontology and epistemology, the plurality of language systems, and the impossibility of communicating intended meaning, the potential to reach consensus without either deception or force becomes impossible. The true character of the society is revealed as anarchy, the realization of which is prevented by the various fictions used to legitimize state power. The anarchistic nature of exiting society remains an undercurrent to the surface relation of power.

The poststructuralist critique of Enlightenment epistemology, therefore, suggests the deconstruction of the state's normative and rational facade. The state is revealed as a set of power relations. Stripped of the illusions which reinforce the dominant ideology, force appears as the real component of social and political relations. Without ideological justification to 
support the institutional structure, social relations are naturally anarchistic. Anarchy is the true, empirical, character of society.

\section{B. The Normative Defense of Anarchism}

Given the heteromorphous nature of possible attitudes, rules, and prescriptions, consensus is not logically possible. Consensus can only be reached using a totalizing conception of society. But, given the plurality of experiences, interests, languages, and epistemological contexts, such universalism can only take the character of totalitarian politics.

If the validity of "norms," "values," and "morals" reside in "popular will," as opposed to transcendental notions of "truth" and "justice," then dominant norms become both ontologically and epistemologically indefensible. The defense of norms, values, and morals takes the form of force disguised as ontological necessity. This condition cannot be mitigated by "majoritarian" forms of democratic practice.

If knowledge, as the construction of truth, cannot be externally validated, and epistemological and ontological plurality are the background for political reality, then anarchism becomes the only defensible normative position. Anarchism denies the state's claims to have the legitimate right to determine what is sacred and profane. Anarchism represents the condition in which the optimal state of external plurality can exist.

The normative character of anarchism comes from the negative character of its assertion. If the actions of states are based on a "positive" claim about the character of the individual, and if that characterization, along with the very idea of "characterization," is rejected, then state actions are reduced to actions of collective force. Within this perspective the burden of proof has been reversed. It is not resistance to the state that needs to be justified, but the positive actions of the state against individuals. Opposition to the state fills the only remaining normative space once the basis for state action has been denied. 


\section{Anarchism and Non-reflexive Individualism}

If a positive basis for anarchism is to be constructed within the epistemological critique of poststructuralism, the issue of "subjectivity" must be addressed. Is it possible to construct a theory of anarchism without the reintroduction of the "representative subject" as historical actor? This can be achieved, I will argue, on the basis of non-ontological assertions regarding the individual within the poststructural epistemology. This, of course, means that the content of subjectivity must be eliminated. The movement of the poststructuralists toward language philosophy offers one possibility.

The political argument revolves around the set of conditions that are necessary for discourse, political or otherwise. Discourse is metaphorical in character. Signs and symbols are transmitted between a sender and a receiver. These two poles are the necessary conditions for discourse. (Jean Baudrillard has used the metaphor of a "living satellite" to describe each participant in discourse. (Baudrillard in Foster, 1983, p. 127.)) Given the poststructuralists' arguments regarding the contingency and plurality of language systems this assertion can provide an epistemologically grounded defense of the most radical form of individualism.

Poststructuralism argues there is a social component to discourse. Discourse is produced in a context in which the episteme underlying the production of statements is validated and reinforced in the process of generating truth claims. The context in which knowledge is produced influences the measure of what qualifies as "knowledge" as well as establishing the semantic limits for discourse. The assertion that there is a role for both "knowledge context," as epistemological milieu, and subjective experience, as the origin of content, suggests both the contingent character of knowledge and the uniqueness of knowledge to each discursive pole.

If the context for discursive statements is both culturally specific and experientially unique, then a double problem for the communication of meaning emerges. On the collective level, each culture will generate a unique set of metaphors with which to construct meanings. There is no linguistic means to impose a universal set of signs and meanings. In addition, on the individual level it must also be concluded that each sensing organism has a unique experiential 
context from which to generate statements. The metaphors of any culture cannot close the gap between the uniqueness of experience and the standardization necessary for discourse.

The relative nature of both epistemological context, as historical milieu, and experience, as a field of sensation unique to each discursive pole, denies not only the ability to form epistemologically sound universals but also demonstrates the fallacy of the claim that moving toward consensual politics will "by necessity" lead to humanitarian political practice. Therefore, to the poststructuralists the "ideal speech situation" discussed by Habermas may provide a condition for the discovery of the majority interest, but it will not, by necessity, limit majoritarianism. There is no implicit plurality of legitimate meanings to compete with the majority.

To the poststructualists the impossibility of communicating perfect meaning in political discourse suggests the impossibility of creating consensual politics. This is the case because both the descriptive and prescriptive statements that form the foundation for consensual politics are reducible to subjectivist claims. The truth value of any such assertions has been dissolved by the poststructuralist critique. Consensual politics is reduced to an expression of power, the ability for one set of metaphors to impose itself onto the discursive system and impose its validating conditions for "truth." The plurality of languages and the individuated nature of sensory experience suggest that each denotive and prescriptive statement must be unique to each individual.

By suggesting the epistemological conditions in which discourse occurs the poststructuralists have generated a claim for a non-reflexive, non-ontological, individualism. This individualism is non-reflexive in the sense that the individual is not turned back on itself to create a justification or definition of "uniqueness," "worth," and "value." Worth does not require a definitional content. This is the case because individual worth is not defined internally, as a representation of some norm or specific character trait. Individuation is imposed externally by the conditions necessary for discourse. Discourse requires a sender and a receiver. Each 
participant reflects, as discourse, the unique experience of that being. The value of discourse is all that must be assumed.

Any assertion of common biological composition among each receiver-sender is mitigated by the uniqueness of the experience that provides the context for discourse. The problem of representation is avoided by the denial of any notion of "essence" in the discussion of the individual. The only assertion is empirical, not ontological. Individuals are biologically separated. Because the environment is infinitely complex, the formation of reflexive content is infinitely pluralistic. Anarchism is the only justifiable political stance because it defends the pluralism that results from individuated meaning in discourse. By logical extension, the individuals who generate that plurality have legitimate claims against the state, which by its nature engages in either totalitarian universalism, or consensual majoritarianism. By exploring the necessary conditions for discourse and in examining the nature of that discourse, poststructuralism suggests an epistemologically based theory of anarchism.

\section{Conclusion}

In the Nineteenth Century the challenge to the "fixed idea" and the "tyranny of structure" raised questions about the epistemological character of modernity. In the Twentieth Century, building on Nietzsche, linguistic theory, and aesthetics, the philosophic movement known as poststructuralism has raised questions about the universalism contained within the modernist tradition. To the poststructuralists, modernity accomplished the subjugation of individuals through the use of an epistemology that prioritizes thought, and its residue "the concept," over what is immediate and sensual. From the assumption of a transcendent "unity" of thought, whether as the "doctrine of the forms" or as "things-in-themselves," the idea of political unity rests its foundation on this epistemological doctrine.

The poststructuralist's view, that the content of subjectivity is relative and contingent upon the discourse that determines the acceptability of statements as "true" or "untrue," questions the assumptions upon which the modern nation state is built. In this view the state acts to impose 
its definition of subjectivity on human beings. The deconstructionist strategy used by the poststructuralists makes possible a critique of all forms of institutional power by challenging the category of "subjectivity" that makes collective political action possible.

Poststructuralism has provided the analytic tools to clarify what Max Stirner suggested in the Nineteenth Century. Stirner argued that the concept of "self" represents a link between culture and institutionalized power. If the self cannot validate its understanding through the belief in transcendent "truth," and if social discourse consists of metaphors, "traces" of reified metaphysics, and power, then the self has only the self through which to validate "being." As a result, Stirner embraces the concept of "ego."

There is a parallel between this idea of Stirner's and Foucault's idea of "power/knowledge," but some distinction is also required. The poststructuralists would deny that any concept of self can be independent of language. The anarchistic conclusions for poststructualism stem from a belief in the multiplicity of possible languages out of which the content for "subjectivity" can be formulated. The imposition of any of those languages as a "metalanguage" appears as a force alien and opposed to the multitextual nature of discourse.

Stirner claimed that the state imposes its will, its thoughts, and its concepts, on the individual body. In defending his "skin" against the tyranny of the concept (Stirner 1973, p. 148.) Stirner is defending the sensing being against the process of objectification at the hands of the state. It is again Foucault that comes closest to the assertions of Stirner in his research on the control of "bodies" in prisons and mental institutions. Foucault described his work as an inquiry into the "technology of the self." (Foucault in Dreyfus and Rabinow, 1983, p. 229.) He was concerned with the various objectification strategies that have been used to control bodies. Because the technologies of the self imposed by institutions are both contingent and speculative Foucault concludes that they should be resisted. (Foucault 1977, p. 211.)

The poststructuralist critique of modernism undermines the project of constructing a universal human identity. In the absence of a meta-concept "human nature" the discourse on human subjectivity moves from a search for "fact" to a discussion of multiple interpretations. 
This shift constitutes a movement from science to aesthetics in the discourse about human beings.

Those who base their attacks on poststructuralism in the claim that the denial of a singular subjectivity makes the formulation of an ethics of resistance impossible misunderstand the focus of the poststructuralist argument. Resistance is formulated against a background of plurality. It is plurality that cultural and political institutions oppose as they promote one form of subjectivity over another. This is precisely why poststructuralism can support liberation movements even though a specific definition of power remains elusive. The struggle for liberation has the character of political resistance to a process of semantic and metaphorical reductionism that serves the interests of control and manipulation.

The act of "reductionism" is not limited to the state, but may take place in a broader cultural context. The liberating potential of poststructuralism is very clearly indicated in the work of Paula Treichler, whose deconstructive reading of United States AIDS policy reveals the homophobia contained within its language. (Treichler 1987) It is also demonstrated in the feminism of Cixous, Irigaray, and Kristeva who see in poststructuralism the potential to remove patriarchy's intellectual foundations.

Ultimately, poststructuralism offers a new opportunity to reformulate the claims of anarchism. By demonstrating how political oppression is linked to the larger cultural processes of knowledge production and cultural representation, poststructualism conveys a logic of opposition. By defending uniqueness and diversity poststructuralism stands against any totalizing conception of "being." Its liberating potential derives from the deconstruction of any concept that make oppression appear "rational." 


\section{Selected References}

Apter, David E., James Joll, eds. 1971. Anarchism Today. Garden City: Doubleday.

Arac, Jonathan, ed. 1986. Postmodernism and Politics. Minneapolis: University of Minnesota Press.

Benhabib, Seyla. 1984. "Epistemologies of Postmodernism: A Rejoinder to Jean-Francois Lyotard." New German Critique 33:103-126.

Botwinick, Aryeh. 1990. Skepticism and Political Participation. Philadelphia: Temple University Press.

Bouchard, Donald F., ed. 1977. Language, Counter-memory, Practice: Selected Essays and Interviews by Michel Foucault. Ithaca: Cornell University Press.

Callinicos, Alex. 1985. "Postmodernism, Post-Structuralism, Post-Marxism?" Theory, Culture, and Society 2(3):85-101.

Deleuze, Gilles. 1983. Nietzsche \& Philosophy. New York: Columbia University Press.

Derrida, Jacques. 1978. Spurs: Nietzsche's Styles. Chicago: University of Chicago Press.

Derrida, Jacques. 1980. Positions. Chicago: University of Chicago Press.

Derrida, Jacques. 1982. Margins of Philosophy. Chicago: University of Chicago Press.

Derrida, Jacques. 1982. "Sending: On Representation." Social Research 49:294-326.

Dews, Peter. 1984. "Power and Subjectivity in Foucault." New Left Review 144:72-95.

Dews, Peter. 1987. Logics of Disintegration: Post-Structuralist Thought and the Claims of Critical Theory. London: Verso.

Featherstone, Mike. 1988. "In Pursuit of the Postmodern: An Introduction." Theory, Culture and Society 5:195-215.

Foster, Hal, ed. 1983. The Anti-Aesthetic: Essays on Postmodern Culture. Port Townsend, WA: Bay Press.

Foster, Hal. 1985. Recodings: Art, Spectacle, Cultural

Politics. Port Townsend, Washington: Bay Press.

Foucault, Michel. 1971. "Orders of Discourse." Social Science Information 10(2):7-30.

Foucault, Michel. 1972. The Archaeology of Knowledge and the Discourse on Language. New York: Pantheon Books.

Foucault, Michel. 1973. The Order of Things: An Archaeology of the Human Sciences. New York: Vintage Books, Random House. 
Foucault, Michel. 1978. "About the Concept of the 'Dangerous Individual' in 19th-Century Legal Psychiatry." International Journal of Law and Psychiatry 1:1-18.

Frank, Manfred. 1989. What is Neostructuralism? Minneapolis: University of Miinnesota Press.

Gordon, Colin, ed. 1980. Power/Knowledge: Selected Interviews and Other Writings 19721977, Michel Foucault. New York: Pantheon Books.

Gould, James A., and Willis H. Truitt. 1973. Political Ideologies. New York: Macmillan Publishing.

Hassan, Ihab. 1985. "The Culture of Postmodernism." Theory, Culture and Society 2(3):119131.

Hoy, David. 1982. "Deciding Derrida." London Review of Books February-March.

Jameson, Fredric. 1984. "Postmodernism, or The Culture Logic of Late Capitalism." New Left Review 146:53-92.

Kaufmann, Walter, ed. 1968. The Portable Nietzsche. New York: Viking Press.

Kellner, Douglas. 1988. "Postmodernism as Social Theory: Some Challenges and Problems." Theory, Culture and Society 5:239-69.

Kramnick, Isaac, ed. 1976. William Godwin: Enquiry Concerning Political Justice. Baltimore: Penguin Books.

Kropotkin, Peter. 1987. Mutual Aid: A Factor of Evolution. London: Freedom Press.

Love, Nancy S. 1986. Marx, Nietzsche, and Modernity. New York: Columbia University Press.

Lyotard, Jean-Francois. 1984. The Postmodern Condition: A Report on Knowledge. Minneapolis: University of Minnesota Press.

Lyotard, Jean-Francios. 1988. The Differend: Phrases in Dispute. Minneapolis: University of Minnesota Press.

Nietzsche, Friedrich. 1956. The Birth of Tragedy and the Genealogy of Morals. Garden City: Doubleday Anchor Books.

Nietzsche, Friedrich. 1957. The Use and Abuse of History. New York: Macmillan Publishing.

Nietzsche, Friedrich. 1973. Beyond Good and Evil. Baltimore: Penguin Books.

Perrot, Michelle. 1981. "Questions of Method: An Interview with Michel Foucault." Ideology and Consciousness 8:3-14. 
Proudhon, Pierre J. 1966. What is Property? An Enquiry into the Principle of Right and of Government. New York: Howard Fertig.

Rabinow, Paul, ed. 1984. The Foucault Reader. New York: Pantheon Books.

Read, Herbert. 1939. Poetry and Anarchism. New York: Macmillan.

Richters, Annemiek. 1988. "Modernity-Postmodernity Controversies: Habermas and Foucault." Theory, Culture and Society 5:611-643.

Ross, Andrew, ed. 1988. Universal Abandon? The Politics of Postmodernism. Minneapolis: University of Minnesota Press.

Roszak, Theodore. 1969. The Making of a Counter Culture: Reflections on the Technocratic Society and Its Youthful Opposition. Garden City: Doubleday.

Silverman, Hugh J. ed. 1988. Philosophy and Non-Philosophy Since Merleau-Ponty. New York: Routledge.

Skinner, Quentin, ed. 1985. The Return of Grand Theory in The Human Sciences. Cambridge: Cambridge University Press.

Strong, Tracy B., ed. 1988. Friedrich Nietzsche and the Politics of Transfiguration. Berkeley: University of California Press.

Treichler, Paula. 1987. "AIDS, Homophobia, and Biomedical Discourse: An Epidemic of Signification." Cultural Studies. 1:3 263-305.

van Reijen, Willem, and Dick Veerman. 1988. "An Interview with Jean-Francois Lyotard." Theory, Culture and Society 5:277-309.

Veerman, Dick. 1988. "Introduction to Lyotard." Theory, Culture and Society 5:271-75.

Walter, Nicolas, Heiner Becker, eds. 1988. Act for Yourselves: Articles from "Freedom" 18861907, Peter Kropotkin. London: Freedom Press.

White, Stephen K. 1988. "Poststructuralism and Political Reflection." Political Theory 16(2):186-208.

Woodcock, George. 1962. Anarchism: A History of Libertarian Ideas and Movements. New York: Meridian Books. 